University of Chicago Law School

Chicago Unbound

Journal Articles

Faculty Scholarship

2005

\title{
United States - Definitive Safeguard Measures on Imports of Certain Steel Products
}

Alan O. Sykes

Gene M. Grossman

Follow this and additional works at: https://chicagounbound.uchicago.edu/journal_articles

Part of the Law Commons

\section{Recommended Citation}

Alan O. Sykes \& Gene M. Grossman, "United States - Definitive Safeguard Measures on Imports of Certain Steel Products," Principles Of Trade Law: The World Trade Organization 225 (2005).

This Article is brought to you for free and open access by the Faculty Scholarship at Chicago Unbound. It has been accepted for inclusion in Journal Articles by an authorized administrator of Chicago Unbound. For more information, please contact unbound@law.uchicago.edu. 


\title{
United States - Definitive Safeguard Measures on Imports of Certain Steel Products
}

\author{
Gene M. Grossman \\ Princeton University
}

\author{
Alan 0. Sykes \\ University of Chicago
}

\section{Introduction}

Since the inception of the WTO, safeguard measures have regularly been the subject of dispute settlement proceedings. The latest in this chain of dispules concerns the definitive safeguard measures imposed by the United States on a wide range of steel products in 2002 .

The safeguards investigation of steel imports was inilialed under U.S. law by the U.S. International Trade Commission (ITC) at the request of the United States Trade Representative (USTR) in June, 2001. The request covered four broad categories of steel products. which were divided into thirty-three categories by the ITC for purposes of data collection. Ultinately, the ITC defined twenty-seven separate "industries" producing steel products within the scope of the investigation. For each of these industries. the ITC proceeded to determine whether imports had increased, and if so, whether increased imports were a substantial cause of serious injury or threat of injury. This analysis resulted in negative delerminations for filteen industries. affirmative determinations for cight industries, and "divided" determinations (a 3-3 votc) for hour industries. ${ }^{1}$

Under U.S. law, a negative determination by the ITC precludes any action by the President to impose a safeguard measure. Affirmative determinations and divided determinations are forwarded to the l'resident for consideration of possible relicf. along

'USITC. Certain Stecl Products, Inv. No. TA-201-73, (USITC Pub. No. 3479, December, 2001). Vol. I (herealier LSITC Report). 
with remedial recommendations that the President is not bound to follow. As to some products, the ITC reconmended that imports from nations with which the United States has preferential trading arrangements - including Canada, Mexico, Israel and Jordan - be exempted from any safeguard measures.

After the conclusion of an inter-agency review process, the President instituted ten distinct safeguard "measures" covering various steel products. which generally excluded imports from preferential trading partners. Eight WTO members (including the European Community) challenged the measures pursuant to the WTO dispute resolution process, and the proceedings were consolidated before a single panel. The panel ruled against the United States on all of the challenged measures, on multiple grounds. The Appellate Body affirmed the ruling in considerable pan, leading to the eventual dismantling of the measures in December, 2003.

The issues before the panel and the Appellate Body were by and large familiar ones, and their opinions broke little new ground. The panel decision is by far the more interesting of the two, but in the end we view both opinions as simply the latest in a long line of unsatisfactory WTO decisions in the safeguards area. Our critique in this regard draws heavily on our prior work, along with the work of other All reporters. Sec Grossman and Mavroidis (2004); Horn and Mavroidis (2003): Sykes (2003); Sykes (2004).

Section 2 lays out some of the key legal issues in safeguards jurisprudence, and describes the state of the law prior to the steel dispute. Section 3 then considers the issues in the steel case, notes some interesting features of the panel report, and shows how the Appellate Body decision adds little to what had come hefore it. Section 4 offers some concluding thoughts about the future of safeguard measures in the WTO system and the need for coherent reforms. 


\section{Legal, Historical and Economic Background}

The legal basis for safeguards in the GATT system was found in Article XIX, which became outmoded with the passage of time in a way that created serious confusion regarding the legal prerequisites for the use of safteguards. With the advent of the WTO, a new Safeguards Agreement elaborated additional legal constraints on the use of safeguards, but failed to resolve many of the central puzzles that had arisen under Article $\mathrm{XIX}$. Appellate Body decisions since the inception of the WTO have only made matters worst, to the point that the legal requirements lor the use of safeguards are largely incoherent, and no nation can employ them without the near certainty of defeat in the dispute resolution process should they be challenged. This section briefly reviews Article XIX. the evolution of national practice under GATT, and the legal developments since the adoption of the Safeguards Agreement and prior to the steel decision.

\subsection{Article XIX and Its Interpretive Puzzles}

GATT Article XLX provides in paragraph (1):

"II, as a result of unforeseen developments and of the effect of the obligations incurred by a contracting party under this Agrecment, including tariff concessions. any product is being imported into the territory of that contracting party in such increased quantitits and under such conditions as to cause or threaten serious injury to domestic producers in that territory of like or directly competitive products, the contracting party shall be free, in respect of such product, and to the extent and for such time as may be necessary to prevent or remedy such injury, to suspend the obligation in whole or in part or to withdraw or modify the concession."

\section{I.1 Unforeseen Developments}

The lirst clause of Article XIX provides that saleguard measures are permissible only following "unforeseen developments" associated with "the obligations incurred by a contracting party." What constitutes an "unloreseen development"? Unforeseen by whom. at what point in time? How does one determine the "effect of the obligations incurred?" 
These questions had a natural answer at the outset of the GATT system. The original GATT negotiations concluded in 1947, with the expectation that GATT would be supplanted within a few years by a new institution to be called the International Trade Organization (Iwhich, of course, never came into being because of a shift in the political winds). The first clause of Article XIX has a natural interpretation in the context of a trade agreement that was expected to be short-lived. The negotiators had made a number of trade concessions to each other in 1947, and Article XIX provided for their suspension in the event that those concessions had an unforeseen, adverse impact on importcompeting industries due to a surge in import competition. To the questions posed above, thereforc, one might answer that an "unforeseen development" was some development that caused the incrcase in inports following a trade concession under the original GATT to be greater than reasonably cxpected. It had to be unforeseen by the GATT negotiators, at the time of the 1947 negotiations. And the import surge had to result from one of the original GATT trade concessions, in the sense that it would not have happened but for some such concession.

But how does one interpret the requirements of Article XIX (1), first clause, in an agreement that remains in force after many years? Consider an import surge thirty or forty years after the agreement was drafted. What would it mean to say that such a surge resulted from the "obligations incurred," particularly if those obligations werc incurrcd decades earlier? Could any such surge have been "foresecn" given the passage of so much time? By whom and when? And how are the answers affected by the fact that GATT negotiations are ongoing, witl new negotiating "rounds" every decade or so? The requirements of the first clause no longer lave a straightforward interpretation in an agreement that lasts for decades rather than a few years, and that is characterized by an ever changing set of commitments. 
For these reasons, GATT practice evolved over time toward ignoring the requirements of the first clause in Article XIX(1). National laws to authorize safeguard measures soon made no mention of them. Section 201 of the U.S. Trade Act of 1974. for example, simply requires the International Trade Commission (ITC) to determine "whether an article is heing inported into the United States in such increased quantities as to be a substantial cause ${ }^{3}$ of serious injury, or the threat thereol." There is no requirement that developments be "unforeseen" or that they result from earlier trade concessions. At this writing, this statute remains the basis for saleguard measures under U.S. law.

Such a development is an understandable conscquence of the difliculties in giving content to the first clause of Aricle XIX in a long-lived agrcement. But as shall become immediately apparent, the absence of this "anchor" for the remainder of Article $\mathrm{XIX}(1)$ creates other problents.

\subsubsection{Serious Injury and Causation}

Under Article XIX. it is not enough that an unforeseen import surge results from a trade concession. The import surge must go on to cause or threaten "serious injury." This phrasing raises other obvious interpretive issues-what is "scrious injury?" How does one determine whether the "cause" of such injury (or threal therenf) is "increased quantitics" of imports?

On the first question, the text appears delibcrately vague. 'the drafters might have made reference to specifics in this regard-lost profits, unemployment. bankruptcies, and the like-but chose to leave the term undefined. Perhaps the best inference is that they

\footnotetext{
'See McGovern (1986. p.291).

${ }^{3} \mathrm{~A}$ "substantial cause" is a "cause that it is important and not less than any other cause." 19 U.S.C. $\$ 2252(b)(1)(B)$.

${ }^{4} 19$ U.S.C. $\$ 2252(\mathrm{~b})(1)(\mathrm{A})$.
} 
did not want to constrain the concept unduly by attempting a definition, and that they would allow a variety of factors into the analysis.

On the question of causation, the logic was nevertheless fairly clear. The unforeseen import surge, resulting from the trade concession, had to be responsible for serious injury. Put differently, the serious injury had to be "caused" by the trade concession. via its effect on the level of import competition, in the usual but for sense of the term "cause." Within this framework, the "exogenous" variable is the trade concession, and the "increased quantities" of imports were those resulting from that concession. Likewise, the level of imports in the absence of the trade concession serves as the baseline against which to measure the "increase."

But now imagine reading out the first clause of paragraph one, as GATT members began to do many years ago. Then, one must simply have "such increased quantities (of imports) ... as to cause or threalen serious injury," as, for example. is required by the U.S. law The baseline for the "increase," import levels prior to a recent trade concession, is no longer available. Further, the only apparent candidate for an exogenous variable is the "increased quantitics" of imports, as there is no longer any background event from which these "increased quantities" result.

Two considerable problems arise as a result. First, how does one now determine whether there are "increased quantities" of imports at all-against what baseline is the increase to be measured?

Second, and more fundamental, how can one treat increased quantities of imports as an exogenous or "causal" variable? Elementary economics suggests that the forces of supply and demand will determine the quantity of inports, just as they do prices and domestic production. If imports and domestic products arc perfect substitutes, for example, then the quantity of imports will equal the difference betwcen domestic deinand and domestic supply at the equilibrium price. That price, in turn, will be determined by the intersection between the domestic demand curve and the total supply curve, 
comprised of the sum of domestic supply and import supply. The exogenous factors in the economic framework are the determinants of domestic supply. domestic demand, and import supply. Domestic demand is affected by such things as domestic consumer tastes and incomes, domestic supply by the domestic costs of inputs into production and the state of available production technology, and import supply by the parallel lactors that affect supply and demand in ollicr countries. The quantity of imports is then a reswll of the interaction of these forces: it is not a causal variable at all.

Lihewise, changes in the quantity of inports will be the result of changes in the determinants of domestic supply, demand and the world price. Increased quantities of imports may result, for cxample, from a fall in the world price due to falling input costs abroad, to improved production technology abroad, or to weakening demand abroad. Increased quantities of imports can also result from an increase in domestic demand attributable, for example, to rising consuner incomes. Finally, increased quantities of imports can result from increasing costs of domestic production reflected in a lefiward shifi of the domestic supply schedule.

Against this backdrop, the question "did increased quantities of imports cause serious injury to a domestic indusirg?" is simply incoherent. Suppose, as an illustration, that the domestic industry suffers a decline due to rising costs. As domestic production falls at the world price. imports will increase to fill the rising gap hetween domestic demand and supply. Are "increased quantities" of imports the "cause" of this "injury?" Certainly not in the usual sense of the term "cause." By hypothesis. what has changed are the costs of domestic firms, and that change results in reduced domestic production and increased imports.

Hence, once the first clause of Article XIX (1) becomes a nullity, it is by no means clear how nations should operationalize their reliance on Article XIX. There is no longer any natural baseline against which to measure "increased quantities," and there is 
no longer any intelligible exogenous variable to assess as potential "cause" of serious injury.

\subsection{The Safeguards Agreement}

For reasons that would take us alield here. relating primarily to the proliferation of "gray-area" measures such as voluntary export restraints during the later years of GATT, the Uruguay Round negotiators concluded a new Agreement on Safeguards. Unfortunately, the Agreement did little to resolve the puzzles raised by Article XIX(1).

On the basic preconditions for reliance on Article XIX, the Agreement largely parrots U.S. law in stating that a "Member may apply a safeguard measure to a product only if that Member has determined.... that such product is being imported into its territory in such increased quantities, absolute or relative to domestic production, and under such conditions as to cause or threaten serious injury to the domestic industry that produces like or directly competitive products." ${ }^{\text {S }}$ Like U.S. law, it omits any reference to "unforeseen developments" or the "effect of the obligations incurred."

The only guidanee as to the meaning of "serious injury" and to the analysis of causation is provided by Article 4 of the Agreement, which states in pertinent part:

1. For purposes of this Agreement:

(a) "serious injury" shall be understood to mean significant overall impairment in the position of a domestic industry;

(b) "threat of serious injury" shall be understood to mean serious injury that is clearly imminent...

2. (a) In the investigation to determine whether increased imports have caused or are threatening to cause serious injury to a domestic industry...the competent authoritics shall evaluate all relevant factors of an objective and quantifiable nature having a bearing on the situation of that industry, in particular. the rate and amount of the increase in inports of the product concemed in absolute and relative terms, the share of the domestic

5id. Art. 2(1). 
market taken by increased imports, changes in the level of sales, production, productivity, capacity utilization, profits and losses, and employment.

(b) The determination referred to in subparagraph (a) shall not be made unless this investigation demonstrates. on the basis of objective evidence, the existence of the causal link between increased imports of the product concerned and serious injury or threat thereof. When factors other than increased imports are causing injury to the domestic industry at the same time. such injury shall not be attributed to increased imports.

Plainly, this provision does not seriously address. let alone resolve, the conundrums presented by modern GATT practice under Article XIX. It does not provide any guidance, for example, on what it means to say that increased imports are a causal variable, or any guidance on what is meant by "factors other than increased imports...causing injury in the domestic industry at the same time." The concept of "serious injury" is left quite vague, and members must simply "evaluate" relevant factors. Further. although the Agreement nowhere refers to "unforeseen developments" and the "effect of the obligations incurred" as a predicate to safeguard measures, it does not specifically provide that Article $X \mid X(1)$, first clause, may lienceforth be ignored.

llence, fundamental questions regarding the legal prerequisites for safeguard measures remain unanswered by the WTO Agreement on Safeguards. These unresolved issues have found their way into WTO disputes.

\subsection{Safeguards in Appellate Body Jurisprudence Prior to the Steel Case}

\subsubsection{The Resurrection of Unforeseen Developments}

As indicated. GATT practice evolved toward ignoring the unforeseen developments requirement of Article XLX, and the Safeguards Agreement says nothing about that requirement. But in its first injportant ruling in a safeguards dispute - Korta -Dairy" -. the Appellate Body overruled the findings of the dispute panel in the case to the

\footnotetext{
"Korea-Definitive Safeguard Measure on Imports of Certain Dairy Products, IVT/DS98/AB/R (1999).
} 
effect that formal compliance with Asticle XIX(1), first clause, is no longer requircd. The Appellate Body instead held that a treaty interpreter "must give meaning and effect to all the terms of the treaty. An interpreter is not free to adopt a reading that would result in reducing whole clauses or paragraphs of a treaty to redundancy or inutility." Article XIX and the Safeguards Agreement are to be read cumulatively it says. and the first clause of Article remains a binding obligation.

As for the proper interpretation of the obligation imposed by Article XIX(1), first clause, the Appellate Body opined: "Il] seems to us that the ordinary meaning of the phrase 'as a result of unforescen developinents' requires that the developments which led to a product being imported in such increased quantities and under such conditions as to cause or threaten to cause serious injury to domestic producers must have heen 'unexpected'. With respect to the phrase 'or the effect of the obligations incurred by a Member under this Agreement, including tariff concessions', wc believe that this phrase simply means that it must be demonstrated, as a matter of fact, that the importing Member has incurred obligations under the GATT 1994, including tariff concessions." The Appellate Body went on to endorse the reasoning of the working party report in the old GATT Hatter's Fur case, ${ }^{9}$ which stated: "... 'unforeseen developments' should be interpreted to mean developments occurring after the negotiation of the rclevant tariff concession which it would not be reasonable to expect that the negotiators of the country making the concession could and should have foreseen at the time when the concession

\footnotetext{
7ld. $\$ 80$.

${ }^{8} \mathrm{ld} .984$.

${ }^{9}$ Sales No. GATl1/1951-3 (Nov. 1951).
} 
was negotiated. ${ }^{10 .,} \quad$ This line of reasoning was repeated by the Appellate Body in Argentina -- Foo/wear. " which also overruled the dispute panel in the case.

Thus, the Appellate Body has fully revived the first clause of Article XIX, and has held in these and subsequent decisions that national authorities have failed to demonstratc their compliance with it. United States - Lamb, ${ }^{2}$ in particular, holds that WTO members must demonstrate their compliance with the Article XIX(1), first clause, prior to the time that a safeguards measure is undertaken. The U.S. ITC's failure to consider the matter in its lamb investigation was "not surprising" given the absence of any reference to it in the governing U.S. statute, but that was no defense for the United States under WTO law. ${ }^{13}$

One can certainly quarrel with the legal soundness of these decisions. Given the uniform practice of ignoring Article XIX(1), first clause, during the latter years of GATT, and its omission from the Saleguards Agreement, it is questionable whether the drafters of the Uruguay Round Agreements had any intention of reviving the obligation-had they wished to alter established CATT practice in this respect, one might argue, they would have so indicated with clarity. The difficult interpretive issucs that the clause raises in a long-lived agrecment, which led to its irrelevance in GATT practice, might also have been noted as a basis for letting it remain dormant.

Having embraced the opposite view, the Appellate Body might have undertaken to explain coherently what Article XIX(1), first clause, now requires. At what point in time must the events in question have been unforeseen-the time of the last tariff concession? What if the last concession on the product in question was decades ago-could anything

101d. 989.

"Argentina-Safeguard Measures on Imports of Footwear. WT/DS1 21/AB/R (1999).

${ }^{12}$ United States-Safeguard Measures on Imnons of Fresh. Chilled or Fruzen Lamb Meal from New Zealand and Australia WTTDSI78/AB/R (2001).

${ }^{13} \mathrm{Id} .973$, 
today have been foreseen? What if the product has heen the subject of numcrous tariff concessions over time-are expectations associated with the last concession the only relevant ones? Why or why not? How docs one cstablish the expectations of trade negotiators as an evidentiary matter? What if there are many negotiators and their accounts of their expectations are incongruent? What if most of them are dead? 'This list of questions is assuredly incompletc.

With regard to the "effect of the obligations incurred," by contrast, the Appellate Body apparently offers a construction that enables this requircment to be trivially satisfied in every case-a member sinply needs to show that it has incurred some obligations with respect to the product in question. It is hard to imagine how a dispute could arise without such an obligation, since a menber with an unbound tarifr could always raise it unilaterally without any need to rely on a safeguard measure. The Appellate Body evidently does not require members to demonstrate that "increased quantities" of imports are attributable directly to any recent trade concession. It suffices for them in argue that in the absence of a tariff binding. they would be able to raise tariffs to eliminate the import surge.

\subsubsection{Increased Quantities}

As noted, Article XIX originally contemplated that "increased quantitics" of imports would be measured against baseline levels prior to 1947 GATT concessions. Having revived Article XIX(1), first clause, therefore, one might perhaps have expected the Appellate Body to require a similar approach to establishing the baseline against which the existence of "increased quantities" is assessed, perhaps by looking to import levels prior to the most recent concession on the product in question. But it has not taken that approacli. 
In Argentina -- Fontwear, "14 the Appellate Body considered a case in which Argentina had adopted the approach embraced some years carlier by the U.S. ITC-a five year "rule of thumb" for establishing the import bascline. The dispute panel in the case concluded that it is "reasonable to examine the trend in imports over a five-year historical period. 15." But the Appellate Body focused on language from the second clause of Article XIX(1) and its counterpan in Article 2.1 of the Safeguards Agreement: "any product is being imported into the territory of that contracting party in such increased quantities and under such conditions as to cause or threaten to cause serious injury." The phrase "is being imported," according to the Appellate Body, "indicates that it is necessary for the competent authorities to cxamine recent imports, and not simply trends in imports during the past five years - or, for that matter, during any uther period of several years. "16" "In our view, the determination of whether the requirement of imports 'in such increased quantities' is met is not a merely mathematical or technical determination. In other words. it is not enough for an investigation to show simply that imports of the product this year were more than last year - or five years ago. Again, and it bears repeating, not just am increased quantities of imports will suffice. There must be 'such increased quantities' as to cause or threaten to cause serious injury to the domestic industry in order to fulfill this requirement for applying a safeguard measure. And this language in both Article 2.1 of the Agreement on Safeguards and Article XIX:1(a) of the GATT 1994. we believe, requires that the increase in imports must have been recent enough, sudden enough, sharp enough, and significant enough, both quantitatively and qualitatively, to cause or threaten to cause 'serious injury'. ${ }^{17}$,

\footnotetext{
${ }^{14}$ Argentina-Safeguard Measures on Imports of Footwear, WT/DS121/AB/R (1999).

15. 1d. :130.

${ }^{16} \mathrm{Id}$.

"Id. 1131.
} 
Thus. the Appellate Body insists that imports must have increased "recently." But how recently, and in what amount? The plurase "recent enough, sudden enough, sharp enough, and significant cnough, both quantitativcly and qualitatively, to cause or threaten to cause "serious injury"' hardly provides useful guidance. The insistence on "not just any increase" but "such increased quantities" as to cause injury is equally unhelpful. And one must again confront the fundamental issue that all of this verbiage avoids--what does it mean to say that increased quantitics of imports "cause" injury when they are, as an cconomic matter, a result of a variety of possible developments? Far from lending badly needed clarification, the Appellate Body's treatment of the "increased quantities" requirement only adds to the confusion.

\subsubsection{Serious Injury}

Like Article XIX and the Safeguards Agreement, the Appellate Body has not attempted to define "serious injury" with any precision. Its focus has been primarily on the text of Article 4.2, whicl simply provides: "the competent authorities shall evaluate all relevant factors of an objective and quantifiable nature having a bearing on the situation of that industry, in particular, the rate and amount of the increase in imports of the product concerned in absolute and relative terms, the share of the domestic market taken by increased imports, changes in the level of sales, production, productivity, capacity utilization, profits and losses, and employment." According to the Appellate Body, the text requires that all of the listed factors be "evaluated" in every case, and it has found safeguard measures wanting under WTO law whenever a member has failed to discuss one or more of these factors in its official report on safeguard action. ${ }^{18}$ The Appellate Body has further held that the obligation to evaluate "all relevant factors" inay extend to factors not raised by any of the parties to the safeguards investigation. ${ }^{19}$

\footnotetext{
${ }^{18}$ See Argentina_Safeguard Mcasures on Imports of Footwcar, WT/DS121/AB/R (1999), \$121.

${ }^{19}$ See United Statcs-Definitive Safeguard Measures on Imports of Wheat Gluten from the European Communities, WT/DS166/AB/R (2001), \{55.
} 
Otherwise. the Appellate Body has simply insisted that serious injury represents "significant overall impairment" as stated in Article 4.1 of the Sateguards Agreement. ${ }^{20}$ It characterizes this standard as "high" and "exacting." It" is not necessary that cvery "relevant factor" reflect industrial decline, however. for serious injury to be present-"a certain factor may not be declinıng. but the overall picture inay nevertheless demonstrate 'significant overall impairment. $22, "$

On the whole, therefore, the Appellate Body has provided relatively little guidance on the meaning of "serious injury," a situation that is perhaps understandable given the sagueness of the pertinent textual obligations. Beyond a requirement that all factors listed in the Safeguards Agreement be "evaluated" in each case, it remains unclear what conditions will support a finding of serious injury or threat, and what degree of deference on the matter will be afforded to national authorities.

\subsubsection{Causation}

The Appellate Body has addressed the causal relationship between inereased quantities of imports and scrious injury in several opinions prior to the stecl case. None of them. however. provides clear answers to the conceptunl difficulties identified in Section 1 .

${ }^{20}$ To date, the Appellate Body has largely refrained from detailed commentary on the reasoning behind findings of "serious injury" hy national authorities. The most notable exception is United States - Safeguard Measures on Imports of Fresil, Chilled or Frozen Lamb Meat from New Zealand and Australia WT/DS 178/AB/R (2001). The U.S. ITC had found lamb prices in the United States to be "depressed" even though they were generally higher than four or live years earlier. And it had found a threaten of serious injury even though prices had risen toward the end of its period of investigation. The Appellate Body held these findings to be insufficient to support the l'TC deternination. Id. T\$157-59.

${ }^{21}$ United States-Safeguard Measures on Imports of Fresh. Chilled or Frozen Lamb Meat from New Zealand and Australia WT/DSI 78/AB/R (2001), \$124.

${ }^{22}$ Argentina--Safeguard Measures on limports of Foolwear. WT/DS121/AB/R (1999), 9139. 
Argenting -- Footwear briefly addresses the proper method for determining whether imports are the "cause" of injury. The dispute panel in the case had indicated that "if causation is present, an increase in imports normally should coincide with a decline in the relevant injury factors. ${ }^{23}$ "The Appellate Body agreed with the panel that "in an analysis of causation, "it is the relationship between the movements in imports (volume and market share) and the movements in injury factors that must be central to a causation analysis and determination.' Furthermore, with respect to a 'coincidenee' between an increase in imports and a decline in the relevant injury factors, we note that the Panel sinply said that this should 'normally' occur if causation is present. ${ }^{24}$ ",

Hence, in its first important statement on the subject, the Appellate tips its hat to the notion that correlation and causation are not the same, but implies that they "normally" go hand in hand. One has no sense that the Appellate Body is aware of (or at least troubled by) the profound conceptual difficulty in confounding the two in a setting where the ostensible "causal" variable is in fact endogenous.

The other Appellate Body opinions on causal analysis focus principally on the socalled "non-attribution requirement" of Article 4.2 of the Safeguards Agreement. It provides that safeguard measures may not be employed unless the "investigation demonstrates, on the basis of objective evidence, the existence of the causal link between increased imports of the product concerned and serious injury or threat thereof. When factors other than increased imports are causing injury to the domestic industry at the same time, such injury shall not be attributed to increased imports." One question raised by this language during the course of various disputes has been whether the harm "caused" by increased imports (again suspending the issue of what it means to treat increased imports as causal) must by itself suffice to cause serious injury, or must simply

${ }^{23}$ Argentina-Safcguard Measures on Imports of Footwear, WT/DS1 21/AB/R (1999), $\llbracket 141$.

${ }^{24}$ Id. F144. 
contribute to serious injury, perhaps along with other faetors. To this ill-posed question. the Appellate Body has responded that "the Agreement on Safcguards does not require that increased imports be "sufticient" to cause, or threaten to cause. serious injury. Nor does that Agreement require that increased imports "alone" be capable of causing, or threatening to cause. serious injury. ${ }^{35,}$

Although increased imports need not account for all of the serious injury, the Appellate Body nevertheless underscores the importance of ensuring that injury caused by "lactors other than increased imports" "not be attributed to increased imports." To make sense of these dual principles. one can only assume that the Appellate Body is concerned about situations in which increased imports have not made any causal contribution to serious injury, and where serious injury is nevertheless wrongly "attributed" to imports.

It has found fault with members' "non-attribution analysis" on multiple occasions. In Chiled Stutes -- Whea Gluten ${ }^{26}$. the volume of imports had risen 38 percent during the five-year period of investigation employed by the ITC. Over the same period, U.S. productive capacity had grown 68 percen. Capacity utilization ut U.S. firms had fallen considerably along with profits, however, and the U.S. IIC had linked the decline in profitability to declining capacity utilization rates. ${ }^{27}$

One issue before the Appellate Body was whether the U.S. ITC had incorrecily "attributed" injury caused by the expansion of U.S. capacity to rising imports. On this question. the Appellate Body noted that had U.S. capacity not risen over the period of investigation. its capacity utilization rate would have fallen only modestly even with the

${ }^{25}$ Inited States-Safeguard Measures on Imports of Fresh. Chilled or Frozen Lamb Meat from Ncw Zealand and Australia WT/DSI78/AB/R (2001). 1170. See also United States-Definitive Safeguard Measures on Imports of Wheat Giluten from the Euronenn Conmunities WT/DS166/AB/R (2001). 170 .

2f Linited States-Definitic Safeguard Measures on Imports of Whcat Gluten from the European Communities W'I/DS $166 / A B / R$ (2001).

${ }^{27}$ Id. 9981.84. 
increased volume of imports. ${ }^{28}$ Further, had imports maintained their market share over the period of investigation, capacity utilization rates still would have fallen significantly due to the increased capacity brought on line. ${ }^{29}$ In the face of this evidence, the Appellate Body concluded that the U.S. ITC had not "adequately craluated the complexities" and had not ensured that injury attributable to cther factors is not attributed to imports. ${ }^{30}$

The Wheat Gluten opinion is problematic in a number of respects. First, as with the other Appellate Body opinions on causation, il does nothing to help with the question of how to conceptualize imports as a causal variablc. Second, taking seriously for a moment the notion that imports are "causal," it was undisputed in the case that they had risen substantially during the period of investigation, while the profitability of domestic producers had fallen. Given the Appellate Body's carlier pronouncements that a correlation of this sort is "normally" present when a causal connection exists, and that impors need not account for all serious injury, one wonders why this evidence was not enough. The logic of the Appellate Body opinion seems to suggest that the problems suffered by U.S. producers were caused by two factors-rising imports, and investment in new capacity that proved unnecessary. In the absence of either factor, U.S. producers would have been considerably more profitable. Why, then, is it inappropriate to attribute at least part of the "serious injury" to imports?

Finally, and as the United States had argucd, much of the increase in capacity was put in place before imports began to increasc. ${ }^{31}$ The sequence of events thus suggested that U.S. producers had invested in new capacity in anlicipation of growth opportunitics, but that imports had increased to capture those growth opportunities and render the new

\footnotetext{
${ }^{28} \mathrm{Id} .985$.

${ }^{29} \mathrm{Id}$. $\$ 86$.

${ }^{30}$ ld. $: 91$.

"Id. $\{87$.
} 
investment uneconomical. It could thus be argued that the unexpected surge in imports was the real "problem." and that investments in capacity were not a conceptually distinct cause of injury but rather a background predicate for the injury caused by imports. To this line of argument. the Appellate Body Responded: "[T]he relevance of an "other factor', under Article 4.2(b), depends on whether that 'other factor' was, or was not, 'causing injury' 'at the same time' as increased imports. Thereforc, the possible relcvance of the increases in capacity added during the period of investigation does not depend on the moment $i_{1}$ time when the increases in capacity occurred, but on when the effects of those increases arc felt, and whether they are 'causing injury' 'at the same time' as increased imports. ${ }^{32,}$ This response simply begs the question as to why domestic investments in new capacity should be considered un "other factor" distinct from imports as a cause of injury, if indeed the anticipated recoupment of those investments was frustrated by an unexpected import surge. The U.S. ITC had treated capacity investments as an alternative cause of injury to be sure (and dismissed them as less important), and the Appellate Body simply seemed to accept it as an "other factor" without rellection.

The decision in linited States -- Lamb $b^{33}$ is similar in this last respect. The U.S. ITC, had considered six factors other than increased imports that might have contrihuted in serious injury: "the cessation of subsidy payments under the National Wool Act of 1954; competition from other meat products. such as beef, pork and poultry; increased input costs: overfeeding of lambs: concentration in the packing scgment of the industry: and a failure to develop and maintain an effective marketing progran for lamb ineat. ${ }^{34.4}$ The Appellate Body again scemed to accept these factors uncritically, and simply

\footnotetext{
32 1d. 988.

${ }^{33}$ United States-Safeguard Measures on Imports of Fresh, Chilled or Frozen Lamb Meat from Now Zealand and Australin WT/DS178/AB/R (2001).

${ }^{34}$ Id, at 1182, 11. 57.
} 
inquired whether the United States had done enough to ensure that injury caused by these factors was not "attributed" to imports. Once again it found the analysis of the ITC wanting, suggesting that it consisted of conclusory assertions without reasoned explanation." Along the way it added: "We emphasize that the method and approach WTO Members choose to carry out the process of scparating the effects of increased imports and the effects of the other causal factors is not specilied by the Agreement on Safeguards. What the Agreement requires is simply that the obligations in Article 4.2 nust be respected when a safeguard measure is applied. ${ }^{36}$. Evidently, members can use any analytical method they wish that complies with Article 4.2, yet the Appellate Body offers no counsel as to what the set of permissible methods might include.

Finally, in United States -- Line Pipe, ${ }^{37}$ the U.S. ITC had considered the possibility that decreased oil and gas drilling was a more important cause of injury than increased imports, and had concluded to the contrary. Once again, however, its analysis was deemed insufficient-the "cited parts of the USITC Report do not establish explicitly, with a reasoned and adequate explanation, that injury caused by factors other than the increased imports was not attributed to increased imports. The passage on page I-30 of the USITC Repor highlighted by the United States is but a mere assertion that injury caused by other factors is not attributed to increased imports. ${ }^{38,}$

In sum, the Appellate Body decisions prior to the steel case regarding the causal analysis required by the Safeguards $A$ greement suggest the following principles: (a) correlation is typically the best evidence of causation; (b) the "other factors" considered

\footnotetext{
${ }^{35}$ Id. $99185-86$.

${ }^{36}$ Id. $\$ 181$.

${ }^{37}$ United States-Definitive Safeguard Measures on Inports of Circular Welded Carbon Qualitv Line Pipe from Korea, WT/DS202/AB/R (2001).
}

${ }^{38}$ Id. 9220. 
by national authorities during the course of their investigations will be accepted uncritically without any reflection as to their logical relevance; and (c) the Appellate Body will not tell nations how to conduct their "non-attribution analysis," but will insist that it contain "reasoned and adequale explanation." which has so far been lacking in every case. In these decisions. the Appellate Body offers no theory as to how imports are to be vicwed as causal, or as to how members should determine what constitutes a potential "other factor." It raults the lack of "adequate explanation" in the decisions of national authorities, yet its own explanation of the permissible role for safeguard measures could hardly be less instructive.

\section{The Steel Dispute}

The recent steel dispute raised all of the issues noted above, and others. The panel decision hints at a partial resolution of the "unforeseen developments" puzzle, but makes little progress on other fronts. The Appellate Body decision breaks no new ground at all, and holds the steel safeguards imposed by the United States to be illegal for predictable reasons in light of the prior cases.

\subsection{The Pancl Decision}

The challenges to the U.S. steel safeguard measures collectively attacked every aspect of their legal basis. The panel exercised judicial cconomy to avoid addressing arguments regarding the definition of "industry" in the U.S. investigation and the existence of serious injury. Its findings instead focused on four areas: the existence of "unforeseen developments" as a predicate for safeguards; the question whether steel imports had increased in "such increased quantities" as to permit safeguards; the causal link between increased imports and injury; and the lack of "parallelism" between the injury analysis and the remedial measures. ${ }^{39}$

\subsubsection{Unforeseen Developments}

${ }^{34}$ United States - Dufinitive Saleguard Measures on Imports of Certain Steel Products, WT/DS248-49. 251-54, 258-59/R (July 2003) (hereafter Pancl Rep.). 
U.S. law has yet to be amended to require that increased imports result from unforeseen developments. and the initial ITC decision in the stecl case predictably paid little heed to the issue. But prior to the imposition of the steel safeguard measures in Murch 2002, the USTR requested additional information from the ITC regarding unforeseen developments, and received a supplemental report on that issue in February. Based in large part on this supplemental report, the United States argued before the panel that four unforeseen developments had contributed to the influx of imports that had injured the U.S. steel industry: the Asian financial crisis; the drop in demand for stecl duc to the dissolution of the Soviet Union; the unexpected strength of U.S. demand for stecl; and the persistent appreciation of the U.S. dollar." Among other arguments, the complainants urged that none of these even' s were "unforeseen," and questioned whether they had resulted in increased imports sufficicnt to justify safeguards.

In assessing these issues, the panel began by noting that the parties agreed that "the point in time at which developments should have been unforeseen is that of the completion of the Unuguay Round." The panel allowed that the Asian financial crisis could constitute an unforeseen developinent "since it took place after the United States last negotiated its tariff concessions on the steel products covered by the investigation." ${ }^{42}$ The same was true of the conscquences for the steel market of the dissolution of the Soviet Union, even though that process had hegun prior to the end of the Uruguay Round. The ongoing strength of the U.S. economy and the U.S. dollar were harder to regard as unforesecable, but the panel concluded that these factors were not viewed by the ITC as unforeseen developments in themselves, but simply circumstances that contributed to the increase in imports that resulted from the developments in Asia and the Soviet Union.

\footnotetext{
"Id. $\$ 10.40$.

"Id. G10.74.

${ }^{42}$ ld. ๆ1 10.80.
} 
Thus, the Lnited States prevailed on the proposition that unforeseen developments had affected the stecl market to some degree.

According to the panel's interpretation of the text of GATT Article XIX, however, the unforeseen developments must produce increased imports that cause serious injury or threat. It was on this issue that the United States failed to persunde the panel, in part because the ITC. lindings of injury were all contained in the original ITC report rather than its supplemental report - at no time prior to its affirmative injury findings did the IIC identify the increased imports that had resulted from the unforeseen developments and analyze their impact on the domestic industry. Such analysis was required, according to the panel, for every line of steel products (every "industry") in which a safeguard Incasure was taken. ${ }^{43}$ Instead. the ITC: had simply asserted in its supplemental report. after the original injury findings had been made. that unforeseen developments had affected the steel market in a general way - as the panel stated. "in light of the complexity" of the matter, a more suphisticated and detailed economic analysis was called for."

The pand's treatment of the unforeseen developments issue might prove helpful in suggesting how to operationalize this requirement in practice, but at the same time underscores that it is a potentially severe hurdle for any nation that seeks to employ safeguard measures. As to the questions posed carlier in this essay - unfurescen by whom? at what point in time? - the panel suggests that the relevant actors are trade negotiators. and that the relevant time is the point when the menber sceking to use safeguards "last negotiated its tariff concessions on the ... products covered by the investigation." The end of the Uinguay Round may be taken to have "reset the clock" on this latter issuc. as GATT memhers formally withdrew from their old GATT obligations

\footnotetext{
"1d. 10.128.

HId. 10.125 .
} 
at the end of the Round and entered a new (WTO) traty, even if the tariff bindings on many products did not change.

In deciding whether events were "unforeseen" by the negotiators at the relevant time, the focus in the first instance will be on whether the events in question took place before or after the conclusion of the negotiations. One can thus imagine the rules here evolving in a manner that is roughly consistent with the rules in nonviolation cases - a presumption might arise that negotiators foresec the results of events that take place before the conclusion of negotiations, and do not foresee the results of events that take place later. ${ }^{45}$ As tariffs decline to minimal levels and unore and more time passes since the last concession. the set of "unforeseen" events will presumably expand and unforeseen developments should become easier to identify.

The panel's demand for linkage between unforeseen developments and particular import increases, and the further requirement that these imports be linked to serious injury or threal, is a substantially new interpretation of the obligations imposed by GATT Article $\mathrm{XLX}(1)$. The great virtue of requiring such a linkage between unforeseen developments and injury, via the effect of unforeseen developments on impor quantities, is that a coherent exogenous variable thereby resurfaces in the analysis - one asks not whether "increased imports" have caused injury in the abstract, but whether particular unforeseen developments have caused injury, via an effect on the relative competitive position of imported and domestic goods. The question that national authorities are asked to answer is once ngain economically intelligible, as it was at the outset of GATT.

But the new obligations inherent in the panel's interpretation do pose some substantial analytical cballenges. It is hardly clear what sort of "more sophisticated and detailed economic analysis" will sullice. Consider the steel case itself: By the panel's reasoning, the United states should have asecrtained precisely how much U.S. imports

\footnotetext{
${ }^{45}$ See Japan -- Measures $\Lambda$ ffecting Consumer Pholographic Film and Paper. WT/DS44/R (1998), 110.79 .
} 
had increased. in cach of twenty-seven steel "industries," as a result of the $A$ sian linancial crisis and the drop in demand for steel inside the old Soviet Union. It should then have analyzed whether this increase caused or threatened to cause serious injury to the relevant industry (as well as provide a convincing "non-attribution" analysis, discussed further below). On the surface, such an analysis stems to call for a glohal general equilibrium model of each segment of the steel market, so that the effect of events in particular overseas markets such as Asia and the former Soviet Union can be simulated with precision. If that son of analysis is indeed required, the time and expense involved could be enormous. The accuracy of such extrcises is also subject to considerable doubt because the results often turn on controversial assumptions. And for many industries, the data necessary to estimate the parameters lor such models will be lacking, and modelers would have litte choice but to fall back on sinulations that rest on seat of the pants guesses about relevant supply and demand elasticities, cross-etasticitics of demand, and the like. The potential boon for consulting economists is readily apparent, but one must harbor no illusions that the task of undertaking such analysis is straightforward - il done properly, it is expensive, time-consuning, and inevitably fraught will the potential for serious error. Perhaps a future reviewing panel would be salisfied with something less daunting (and tbus less rigorous and even more error prone), but the question of what will surfice as a "reasoned and adequate explanation" of the linkage between unforcscen developinents and injury remains unclear at best.

The problem of "non-attribution" might also appear to become more tractable under the panel's interpretation of "unforeseen developments" - one night say that as long as the unforeseen developments cause increased imports, in turn resulting in injury or threat. then by definition injury has not been "attributed" to any factor other than imports. The task of identifying the other faetors to which import-related injury must not be "artributed." and of assessing their impact. could arguably be put to the side. Conceptual issues still remain. however, as to what is pernitted to "count" as an 
unforeseen development. Imagine, for example, an "unforescen" shock in the domestic market for inputs into steelmaking that raises the cost of steel production in the United States. U.S. steclmakers raise their prices to cover costs, and imports llood into the U.S. market to undercut the price increases and market shares of domestic firms. Such "increased imports" may surely be said to cause injury (relative to a counterfactual world in which the impons are not permitted to increase), and to result from the unforeseen developments in the domestic input market. But are safeguard measures appropriate when the root cause of injury is a shock in the domestic economy? Or would safeguards to remedy such injury be impermissible because the injury caused by the domestic shock is wrongly "attributed" to imports? Nothing in the WTO decisions thus far afford much help with such matters, an issue about which we will say more below in connection with the "non-attribution" problem.

\subsubsection{Increased Imports and the Baseline Question}

Taking its cue from earlier Appellate Body decisions, the panel held "that the use of the present tense in the verb phrase 'is being imported' in both Article 2.1 of the Agreement of Safeguards and Article XIX:(1)(A) of the GATT 1994 indicates that it is necessary for the competent authorities to examine recent imports and that the incrcase in imports was 'recent'." ${ }^{46}$ Further, "the emergency naturc of safcguard measures calls for an assessment of whether imports increased suddenly so that the situation became one of emergency."47 And finally, "[i]n light of the Panel's above conclusion that the competent authority must have determined that imports increased suddenly and recently, the Panel will generally focus its analysis on the situation of imports in the more recent period that preceded the end of the period of investigation." ${ }^{418}$

\footnotetext{
${ }^{46}$ Panel Rep. $\$ 10.159$.
}

${ }^{47}$ Id. $\$ 10.166$.

${ }^{48}$ Id. 710.175. 
The panel then proceeded to examine the data on import trends for each of the ten product categories covered by the challenged measures. In most instances, the panel generated a graph representing the import volume and markel share data over the fiveyear period of investigation employed by the ITC. Because the panel's focus was on the "more recent period that preceded the end of the period of investigation," the graph for cach product calegory says much about how the panet came out in each case. We reproduce four of the graphs below for purposes of illustration:

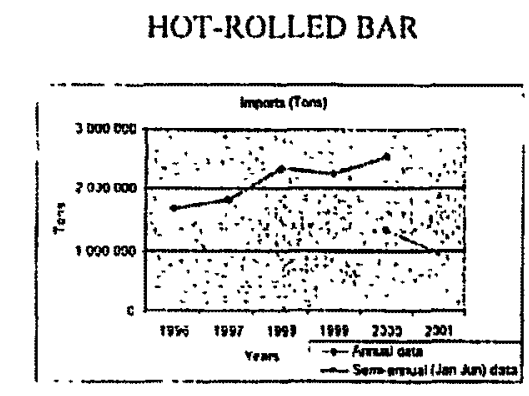

\section{STAINLESS STEEL ROD}

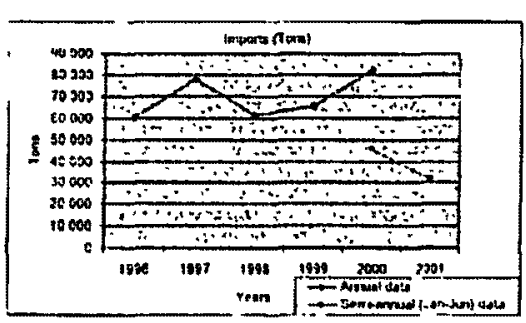

REBAR

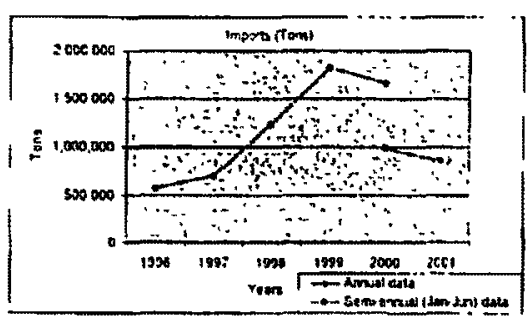




\section{STAINLESS STEEL BAR}

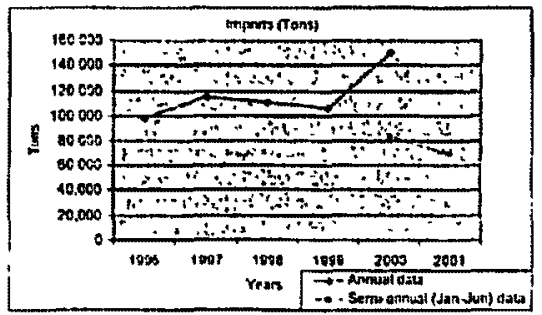

For both hot-rolled bar and stainless steel rod, the panel found that the ITC report did not contain a "reasoned and adequate" explanation of why imports had increased. Regarding hot-rolled bar, the panel focused on the ITC's "failure to account for the most recent data from interim 2001...The decrease from interim 2000 (1.34 million tons) to interim 2001 ( 952.392 tons) represented a decrease by $28.9 \%$, whereas the increase in the year-10-year period before (1999 to 2000) that was characterized as "rapid and dramatic" was merely $11.9 \%$. In light of this decrease in the most recent period. the Panel does not believe that the trend of imports from 1996 to 2000 (an increase by 52.5\%) is sufficient to provide a basis for a finding that. at the moment of the determination, hot-rolled bar is being imported in such increased quantities."'t4

The analysis was similar in many respects for stainless stecl rod. "The USITC relied on the increase occurring between 1996 and 2000, with the largest increase from 1999 to $2000(25 \%)$. The decline between interim 2000 and interim 2001 was acknowledged, but the USITC did not give an explanation why it nevertheless found that there was an increase of imports in absolute numbers. This failure is particularly serious since this decrease (by $31.3 \%$ ) was sharper than the preceding increase, and, as a matter of proportion. offset the increase of the two preceding years."

\footnotetext{
I9 Id. 110.205.

${ }^{50}$ Id. ๆ10.267.
} 
For rebar, by contrast. the panel accepted the ITC finding of increased imports: "In light of the tripling of imports, the decrease over the last 18 months is not significant enough in order to stand in the way of a conclusion that rebar "is being imported in such increased quantities". ${ }^{51}$ l.ikewise, as to stainless steel bar, the panel found that "in the light of the signilicant inerease from 1999 to 2000 (19.3 percentage points), the decline by 3.3 percentage points from interim 2000 to interim 2001 is, contrary to what the European Communities has stated. insignificant. It simultancously does not detract from a finding that imports, relative to domestic production, remain at high levels so that stainless steel bar 'is being imported in (such) increased quantitics." $\$ 2$

For two product categories, tin mill products and stainless steel wirc. the panel ruled that the United States failed to demonstrate the presence of increased imports because it had relied on the separate opinions of ITC Commissioners who had defined the relevant "industries" in different ways. loor example, some treated "tin mill products" as a separate ildustry. while another included tin mill products in a broader industry. The panel was of the view that the separate findings reached in such fashion could not collectively constitute a "reasoned and adequate" explanation for the finding of increased imports.

The panel's reasoning focused on two issues in each instune'; whether imports had risen substantially over the entire period of investigation (the five-year period ordinarily used by the ITC as its baseline), and whether any rece'm downtrend in imports had undercut the finding of an overall increase. Implicitly, recent trends carry more weight than the five-year trend. but a modest recent decline in imports would not prevent a finding of increased imports if the five-year trend was more dramatically upward.

\footnotetext{
"1d. 110.225 .

${ }^{52}$ Id. 110.254.
} 
The panel's approach is at least somewhat puzzling, for a couple of reasons. First. having held earlier that the United States should have linked import increases to the Asian tinancial crisis and the dissolution of the Soviet Union, one might have expected the panel to suggest that the timing of those events defines the baseline for measuring the increase in imports. Instead. as under longstanding U.S. practice, the panel (and the complainants) seems to accept that the arbitrary five-year baseline is permissible in principle: "The conplainants do not challenge the choice of" a five-year period of investigation per se. Complainants rather disagree with the fact that, generally, the USITC did not focus sufficiently on the situation of imports in the latest part of the period of investigation." ${ }^{53}$ Second, had the United States in fact linked an increase in imports to unforeseen developments such as the Asian financial crisis and the dissolution of the Soviet Union. and had it shown that the extra imports resulting from these developments were sufficient to cause serious injury, would that not have been enough to establish a basis for safeguard measures? Why must the United States additionally show a sudden, sharp and significant increase in total imports? Should the right to safeguard measures be eliminated, for example. if the effets of the unforeseen developments, working through increased imports, had been reinforced by a slowdown in U.S. demand, which might have caused additional injury but served to temper the growth in import volume?

The great emphasis on the most recent year or months of data is peculiar in another respect. The time series for imports of any good may exhibit significant volatility for a variety of reasons. and the notion that WTO members would wish to condition the right to use safeguards heavily on the most recent import fluctuations. which may be quite unpredictable when an investigation is initiated, seems odd even if it has some arguable textual basis. The preamble to the Agrecment on Safeguards emphasizes the importance of "structural adjustment." much as U.S. law has long set forth the alternative goals of

\footnotetext{
sild. qi 0.160.
} 
promoting industrial competitiveness or facilitating an orderly industrial contraction. ${ }^{54}$ If these stated goals are to be taken seriously. they concern measures to address long-term structural trends. Likewise, Article 7 of the Safeguards Agreement provides that safeguard measures may be imposed for four years, with the possibility of an extension to eight years. The potential duration of the measures is also suggestive of the notion that they address long-term trends in industrial competitiveness. If this is rigltt. why should the opportunity to utilize safeguard measures turn critically on recent import fluctuations rather than long-term import trends? One wonders whether the panel here. and the Appellate Body gencrally, has turned the matter completely on its head.

\subsubsection{Causation and the "Non-attribution" P'roblem}

The panel found fault with the ITC analysis of causation for nine of the ten "industries" covered by the U.S. safeguard measures. In cach instance, it held that the ITC failed to demonstrate a causal link between increased imports and injury, that it failed to ensure that injury caused by other factors was not "attributed" to imports, or both.

\subsubsection{Demonstrating the Causal Link to Jmports}

Again taking its cue from prior decisions, the panel suggested that a causal linkage between increased imports and injury might be established in onc of two ways: through a "coincidence" analysis, or through an analysis of the conditions of competition. A coincidence analysis examines the "temporal relationship between the movements in inports and the movements in injury factors." 55 Such coincidence is "nomally" evident "if causution is present." 56 although the suggestion that a temporal lag may exist between

\footnotetext{
${ }^{5.4}$ See 19 U.S.C. $\$ 2251(b)$.

${ }^{55}$ Panel Rep. \$10.299.

${ }^{56} \mathrm{ld} . \$ 10,300$.
} 
import increases and injury "may have merit in certain cases." ${ }^{37}$ Where a clear coincidence exists, "no further analysis is required of the competent authority," save for a careful non-attribution analysis. ${ }^{58}$ Where coincidence is lacking or an analysis of coincidence has not been undertaken, the competent authority must explain its absencc and must show causation convincingly through other means.

According to the panel, an analysis of the conditions of competition requires the conipetent authority to consider the factors enumerated in Article 4.2(a) of the Safeguards Agreement: changes in import volumic, import market share, domestic sales, production, productivity, capacity utilization, profits and losses, and employment. Other unenumerated factors may also be relevant. ${ }^{59}$ Further, "price...in the Pancl's view, is an important, if not the most important, factor in analysing the conditions of competition in a particular market...we consider that relative price trends as between imports and domestic products will often be a good indicator of whether injury is being transmitted to the domestic industry...given that price changes have an immediate effect on profitability, all other things being equal."

Against this backdrop, the panel proceeded to consider the analysis of the ITC as to cach of the challenged measures. In the important category of certain carbon flat-rolled steel (CCFRS), for example, it found "that there was no coincidence between. on the one hand, import trends and the situation of the domestic industry of CCFRS, as rellected in data for production, net commercial sales, productivity and capacity utilization of the domestic CCFRS. We have also found that there was a lack of coincidence between import trends and declines in domestic operating margin... We did discern coincidence,

\footnotetext{
${ }^{57} \mathrm{Id} .910 .310$.
}

${ }^{35}$ Id. $\$ 10.307$.

${ }^{\$ 9} \mathrm{Id} . \$ 10.318$.

${ }^{60} \mathrm{ld} .1110 .320$. 
albeit lagged, between increased imports, on the one hand, and employment, on the other hand...Having taken into consideration all of the foregoing, in the Pancl's view, ovcrall. coincidence did not exist." injury factors, it was for USITC to provide a compelling explanation as to why a causal link was considered, nevertheless, tn exist." "it2

The ITC's analysis of the conditions of competition for CCFRS was then found deficient as well. The panel first suggested that the product category might be too broad for such an analysis to be undertaken at all in convincing fashion. Further, the ITC. apparently relied heavily on evidence of import underselling and downward price trends for both inports and domestic produets for two sub-products in the CCFRS category, without explaining "why pricing data for the other three items that constituted CCFRS were not specilically considered." And. "while some of the domestically produced constituent items were undersold by the import counterparts at particular points during the period of investigation. this was not necessarily the case for the entire period of investigation."63 Thus, the conditions of competition analysis failed to support the existence of a causal link between increased imports and injury.

As to other product lines, the panel found the ITC's analysis more convincing. For fittings, flanges and tool joints (Fly J), the panel examined the relation between imports and indicators of injury, and noted that "clear coincidence exists between the upward trend in imports and the downward trend in the injury factors, except for productivity." Because the ITC report had not analyzed this coincidence in detail, however, the panel also found that a conditions of competition analysis was required to

\footnotetext{
"id. $1910.374-75$.

62Id. 110.376.

${ }^{63}$ Id. $\$ 10.379$.
} 
support the ITC's finding of a causal link. ${ }^{\text {th }}$ In that regard, the panel reviewed data assembled by the ITC showing that imported products significantly undersold domestic products during the period of investigation, and on that basis concluded that the conditions of competition analysis supported the existence of a causal link.

In the case of hot-rolled bar, the panel noted that the ITC had not undertaken a coincidence analysis. But as part of its analysis of the conditions of competition, the ITC assembled data on market penctration by imports along with import and domestic prices. The data were presented in the following graph:

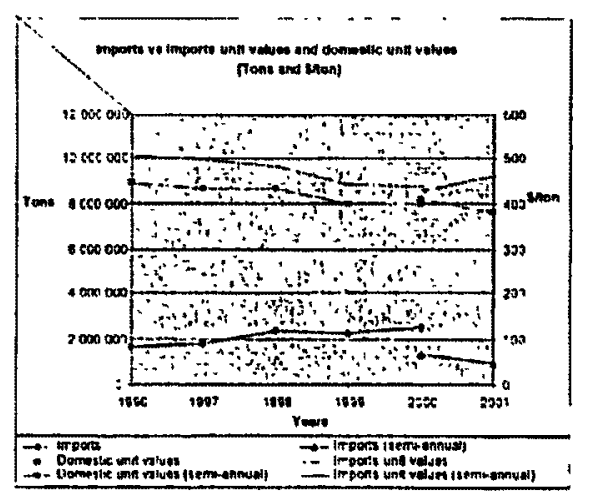

Based on these data, the panel concurred that a causal link was present - "[t]he USITC explained that domestic prices declined in an effort to mitigatc the crosion of markct share ... On the basis of the foregoing, overall, we find that the USITC's conditions of compctition analysis was compelling." ${ }^{\text {"65 }}$

It would be unfair to fault the panel for following the analytic lead of the Appellate Body and the ITC, but in doing so it followed them to the land of economic gibberish. The panel insists that the linchpin in the search for causation is a search for coincidence. The irony of that phrasing is glaring - the Random House English

o4ld. 110.516.

${ }^{65}$ Id. rq10.429-30. 
dictionary defines "coincidence" as "a striking occurrence of two or more events al one time apparently by mere chance." The most clementary statistics class teaches that currelation is nol causation, and the problem is nol amelioraled by relabeling correlation as coincidence.

Further, as explained earlier, the problem is actually much more fundamental. It is not disreputable to examine correlation as an aid to an exploration of causation with appropriate caveats. But one can only do so when one variable is a logical candidate for the cause of the other. Import quantities do nol couse anything - they are simultaneously deternined along with prices, domestic output. domestic employment, and so on. It makes no more sense to say that increased imports caused a decline in domestic production. for example. than to say the exact opposite.

At this point. the pancl's analysis would seem to involve internal inconsistency. On the one hand, it would require the complainant to identify "unforescen developments" that are linked to increased imports which in turn liave caused scrious injury or threat. But on the other hand it would prescribe a separate causation analysis in which the unforeseen developments play' no role. If the panel's requirements for establishing the existence of unforeseen developments have heen met - namely, that the domestic industry experienced exogenous shocks that causcd import volume to rise and conditions to deteriorate - mustn't the requirements for causality have been met as well? What additional information can the examination of coincidence provide?

The "conditions of competition" analysis that serves as an alternative to coincidence analysis is no more comforting. To the extent that the panel, like the ITC. finds evidence of import "underselling" to be persuasive evidence of ciasalion, an cconomist would respond that persistent underselling by imports is simply evidence that they are of lower perceived quality for some reason. It says nothing about a causal link between anything and anything else. Likewise, to the degree that a high degree of correlation exists between the price series for imported and domestic goods. that fact is 
some evidence that the goods are reasonably close substitutes in consumption. Again, no inference of "causation" is supported, as indeed there is no intelligible causal variable under examination.

To be sure. cases will arise in which "coincidence" is relatively stronger or weaker. Cases will arise in which imported goods undersell domestic goods, and many cases will arise in which import and domestic price trends are highly correlated. It will thus be possible for importing nations to demonstrate "causution" with some regularity using the tests that the panel applies. But if any relationship exists belween that set of cases, and the set of cases in which safeguard measures are appropriate on some principłed basis, it will arise only by "coincidence."

\subsubsection{The Non-Attribution Problem}

Following the lead of the Appellate Body, the panel makes clear that the presence of a "causal link" between imports and injury, established as above, is not enough to satisfy the requirements of the Safeguards Agreement. If other factors have also contributed to injury, the "competent autliorities must separate and distinguish the injurious effect of the increased imports from the injurious effects of the other factors." This excrcise is required cien though imports need not be solely responsible for injury, but must merely have contributed to it. A proper non-attribution analysis also determines the permissible scope of the safeguard remedy - the Appellate Body had ruled in United Siates - Lime Pipe that safeguard measures may only remedy the injury attributable to increased imports, not that attributable to other factors. ${ }^{67}$

For a number of product lines, the panel found the ITC's non-attribution analysis to be lacking. The panel's approach, as in previous cases, was simply to accept at face value the "other factors" put forth by the respondents at the ITC, with no discussion as to

\footnotetext{
${ }^{66} \mathrm{ld} .710 .329$.
}

${ }^{67}$ ld. fil 10.338 . 
how or why they are appropriate or inappropriate. The panel would then check to see whether the ITC had confidently distinguished the injury attributable to the factor in question, and ensured that such injury was not attributed to imports.

We offer one illustrative example of the analysis: In the case of hot-rolled bar, as noted above, the panel accepted the ITC's analysis of the conditions af competition as a basis for finding a causal link between increased imports and injury. But the respondents argued before the ITC that injury was caused, inter alia. by increased input costs for domestic producers. what the pancl termed increases in the costs of goods sold (COGS). The ITC acknowledged that COGS had risen during part of the period of investigation, but argued that import competition had suppressed prices and prevented domestic firms from recouping their higher costs. On that basis, the ITC concluded that imports were the more important cause of injury. The panel evidently considered this analysis too cursory, thus falling short of a "reasoned and adequate" explanation. The panel linted, however, that if the ITC had gone further in its analysis, it might have been able to defend its conclusion. In particular, the panel noted that there was a general lack of "coincidence" between changes in COGS and operating margins for donestic producers. Had changes in COGS "played a significant role in the situation of the domestic industry, one would have expected operating margins to increase while COGS was decreasing. ${ }^{168}$

The panel's discussion of the non-attribution requirement suffers from the sanic logital flaws as the trealment of the issue in prior cases. Its analysis of the COGS factor for hot-rolled bar illustrates the lundamental problem. An increase in input costs for domestic firms will lead them to institute price increases if they can. But, as may have been the case in the hot-rolled bar market, import competition may prevent such price increases. The price increases that are attempted by domestic limns. caused by rising

${ }^{63}$ Id. $\$ 10.440$. 
input prices, may thus be the cause of greater import volumes, which restrain price increases and leave domestic firms in a weakened financial situation.

The pand insists, however, that the injury attributed to rising COGS must be distinguished from the injury attributed to imports. As the above discussion makes clear, this task is logically impossible. The inports themsclves result from increases in COGS, and so how can the effects of the two possibly be distinguished? Putting it differently, the causal variable in this scenario is an increase in domestic input costs. The result is both an increase in imports, and a weakened financial situation for domestic firms. For the same reason, the proposition that a permissible safeguard measure can address the injury caused by increased imports, but not the injury caused by rising COGS, is also fundamentally incoherent.

The pand's suggestion that one can analyze the importance of COGS by looking at the coincidence between changes in COGS and operating margins is silly. Other things being equal, incruases in COGS will surely tend to lower operating margins, but many other factors in the market are variable over time, and the absence of a "coincidence" between changes in COGS and operating margins simply indicates that other things are happening simultaneously - a clear demonstration of why "coincidence" and causation are two different things. Obviously, the presence of other factors varying sinultaneously cannot negate the fact that increases in innut costs, other things being equal, are disadvantageous for domestic producers.

The ultimate issue here is a simple one - should safeguard measures be permilted when the cause of injury to a domestic industry, and the cause of rising imports, is a shuck to the cost structure of domestic firms? There may he good reasons to answer this question yes or no, but the analysis of the panel merely masks and confuses it.

\subsubsection{Parallelism}

The "parallelism" requirement stems from Argentina -- Footwear. The Appellate Body there held that a correspondence must exist between the imports included in the 
analysis that led to the injury determination. and the imports covered by the safeguard measure. ${ }^{69}$ Thus, for example. if imports from Canada were part of the data on which the injury finding rests, imports from Canada cannot be exempted from any subsequent saleguards remedy.

The legal basis for the parallelism requirement is shaky. Pauwelyn (2004) criticizes the requirement and argues forcefully that the real issue is whether Article XXIV of GATT. pertaining to the formation of customs unions and free trade areas, either requires or permits members of such entities to exempt imports from other members from saleguard measures. This question thus far has no clear answer.

Whatever its merits, the parallelism requirement is established in the cases, and the United States undertook to argue that it had complied. The original ITC determination had aggregated imports from all sources, however, while the cventual safeguard measures had largely excluded imports from NAFTA countries, Isracl and Jordan. The ITC was asked to revise its analysis to exclude these imports in its supplemental report to USTR. It did so, and reached the same conclusions for each industry.

The panel took issue with the analysis for several reasons. In several instances. the ITC had not made clear that it had properly excluded imports from Israel and Jordan in its revised analysis. The ITC also failed to explain to the panel's satislaction why its lindings remained the same despite the fact that a smaller quantity of imports was involved after the parallelism adjustments. In addition. the panel held that the ITC was obliged to repeat its non-attribution analysis based on the revised import totals, and that it had failed to do so in the supplemental report.

In the interest of parallelism. therefore, the pancl would lave the ITC revise its import data. and thereafter undertake the same conceptually flawed analyses of

\footnotetext{
${ }^{69}$ ld. $910.590-91$.
} 
coincidence, conditions of competition, and non-attribution. The excluded imports would become an "other factor" to which injury from the included imports could not be attributed. Such exercises are no more valuable with the revised data than with the original. Until a logically sound approach to the question of causation emerges, the requirement of parallelism is just a sideshow.

It is also somewhat peculiar that neither the panel nor the prior pertinent decisions draw any connection between the parallelism issue and the unforeseen devclopments issue. If the United States is obliged by Article XIX to draw a connection between injury and developments in Asia and the former Soviet Union, is it not possible that such injury was transmitted through an effect on imports from particular sources, rather than an effect on all imports or on world prices? Does the answer to that question have any implications for the permissible scope of the safeguard remedy, or for the possible exclusion of imports from particular sources?

\subsection{The Appellate Body Decision}

The Appellate Body affirmed the panel in most pertinent respects, or exercised judicial economy to avoid reaching the issues raised. ${ }^{70}$ We can thus address its decision with considerable brevity.

\subsubsection{Unforesecn Developments}

Much of the U.S. appeal on this issue consisted of a challenge to the "standard of review" enployed by the panel - a requirement that the U.S. competent authorities provide a "reasoned and adequate" explanation for their findings. The Appeliate Body essentially affirmed the standard employed by the pancl, and we have no quarrel with the general principle that national authoritics should set forth findings with enough elarity and logical reasoning for reviewing panels to be able to assess then.

\footnotetext{
${ }^{70}$ United States -- Definitive Safeguard Mcasures on Imports of Centain Steel Products. WT/DS248-49, 251-54, 258-59/AB/R (November 2003) (hereafter App. Body Rep.).
} 
The Appellate Body also concurred with the panel that a member proposing to invoke safeguards must demonstratc that unforeseen developments have led to increased imports for each "industry" covered by a safeguard measurc." Here too it affirmed the finding that the ITC had failed to make such a showing with a "reasoned and adequate" explanation. ${ }^{72}$ We lave no quarrel with this principle either as a general matter. The treaty text requires the preconditions for safeguards to be met for any "product" covered by a safeguard measure. When. as in the steel casc. national authorities determine that a number of different "products" are imvolved and proceed to define a number of separate "industries" to investigate, it is appropriate to require that the preconditions for safeguard measures be met in cach industry.

But the Appellate Body opinion does not speak to the deeper issues raised by the unforeseen developments requirement. It expressly states that it offers no ruling on the question whether the developments identified by the United States - the Asian financial crisis, the dissolution of the Sovict Union, and so on - actually constitute "unforeseen developments" as a legal matter. ${ }^{73}$ It thus offers no guidance on how one determines what is "unforeseen," or what is pernitted to "count" as an unforeseen development. Most importantly. it does not address the ultimate issue, raised implicitly by the panel's analysis. as to whether national authorities nust convincingly link all of the "serious injury" caused by "increased imports" to the underlying "unforeseen developments." If indeed they must. then the requisite analysis becomes somewhat better grounded in a coherent cconomic theory" on the one trand, but the lask of producing a "reasoned and adequate" justification for a safeguard measure becomos all the more daunting on the other.

\footnotetext{
${ }^{71}$ Id. 919.

$721 d .9326$.

${ }^{33}$ Id. 1269.
} 


\subsubsection{Increased Imports}

Here, the Appellate Body reaflirmed the principle set forth in Argentina Foorwear that a mere increase in imports is not enough to satisfy the requirement of "such increased quantities" as to cause injury. It quoted with approval its prior reference to a requirement that "the increase in imports must have been recent enough, sudden enough, sharp enough, and significant enough. both quantitativcly and qualitatively, to cause or threaten to cause 'serious injury, ${ }^{\prime 7 \cdot 4}$ and found that the pancl laad interpreted this standard currectly. In so doing, the Appellate Body did nothing in our vicw to clarify the practical application of the standard. Likewise, the decision docs little to explain the logic behind the standard - why do the consequences of "unforesecn developments" not unfold slowly at times, so that the resulting increase in imports is not particularly sudden or sharp? And, at the risk of seeming repetitive, what sense does it make to fret about the time period over which increased imports may or may not have caused imjury, when the law offers no coherent theory of how imports cause anything? On these fundamental conceptual issues relating to the increased imports requirement, the marginal contribution of the opinion is nil.

Regarding the pancl's findings with respect to specific product categories, the Appellate Body for the most part affirmed the panel's findings to the extent that they were appealed by the United States. We critiqued the panel's analysis at some length above on these issues, and will not repeat the discussion here.

The Appellate Body did reverse the panel's findings with regard to tin mill products and stainless steel wire. Contrary to the panel's conclusion, the Appellate Body held that the findings of different Commissioners, who had defined the industries in varying ways, could in principle suffice as a "reasoned and adequate" explanation for a finding of increased imports. ${ }^{75}$ Nothing in the treaty text precludes an aggregation of

\footnotetext{
${ }^{71}$ Id. $\$ 345-46$.

${ }^{75}$ ld. $: 91416,429$.
} 
judgments in this lashion, nor is it logically inconceivable that analyses hased on different conceptions of the "industry" might nevertheless justify a linding of increased imports. Having resersed the panel on this pnint, however, the Appellate Body found it unnecessary to complete the panel's analysis because it held the safeguard mcasures for tin mill products and stainless steel wire to be illegal on other grounds. ${ }^{\text {in }}$ The reversal of the panel here may be of sume modest comfort to the United Stales, with its history of ITC Commissioners who oftun arrive at different delinitions of the relevant "industry" in safeguards proceedings. but seems to be of modest conceptual importancc.

In sum, as with its treatment of the unforeseen developments requirement, the Appellate Rody decision adds nothing of significance to its previous decisions beyond tacit approval of the analysis conducted by the panel on several of the product categories. Our thoughts on that analysis are set forth above.

\subsubsection{Parallelism}

The Appellate Body agreed with the panel that the ITC had not shown that it had properly excluded imports from Canada, Mexico. Israel and Jordan in reaching its findings. It emphasized especially that the ITC had not considered the excluded imports as an "other factor" in a proper non-attribution analysis. ${ }^{77}$ We have no quarrel with the factual proposition that the ITC's reasoning on this front was murky, although the task of fixing the problem remains confounded by the absence of any colierent way to identify the impact of the relevant set of "increased imports," or to separatc the injury caused thereby from injury caused by other factors. Until a conceptual framework for identifying the relevant exogenous variables and assessing their impact is aniculated, it is simply not tear how to implement a requirement of parallelism. And absent an intelligible theory as

\footnotetext{
${ }^{76} 1 \mathrm{~d} .9431$.

7 Id. 17456 .
} 
to when safeguard measures are appropriate and when they are not, it is impossible even to say whether a "parallelism" requirement makes sense.

\subsubsection{Causation}

Because its rulings on the unforeseen developments, increased imports and parallelism issues sufficed for finding that each of the ten challenged measures violated WTO law, the Appellate Body declined to consider the panel's analysis of the causation issue. It simply referred the partics to its prior rulings for lurther "guidance." rulings with which we have already taken issue.

In sum, unlike its prior rulings in the Safeguards area, the Appellate Body ruling in the stet dispute offers virtually nothing of conceptual importance. To the extent that any important new law was made, it consisted of affirming the reasoning of the panel on certain key points that have already been discussed extensively above. Nothing in the opinion resolves any of the conundrums raised by prior Appellate Body decisions.

\section{Concluding Commentary}

Our review of the steel dispule suggests how difficult it will be for WTO members to use safeguards going forward without a prospect of near certain defeat when a complaint is brought against them. Members must demonstrate the existence of unanticipated developments, persuade that they were "unforescen," convincingly trace their impact on increased imports, demonstrate that nuch of the import surge is sufficiently "recent," convincingly show the relation between the imports and serious injury to an appropriately defined "industry," and convincingly show that "other factors" have not caused the injury attributed to increased imports. And they must accomplish these things in a theoretical vacuum, where neither the trenty text nor the Appellate Body decisions to date ofler any clear cxplanation of what it even means to say that "increased imports" have "caused" or threatened to cause serious injury, how one identifies the "other factors" that might be responsible for injury, and how one attributes injury among its various causes. Because it is unclcar what the law requires as a conceptual matter, it is 
exccedingly difficult to comply with it, and one can hardly fault national authorities for their inability to offer a "reasoned and adequate" demonstration of their lidelity to the law.

To be sure. some observers may welcome these developments. For those who believe that safeguard measures are nothing more than wasteful protectionism, insurmountable hurdles to their use will have appeal. But the literature is in fast rather agnostic on the use of safeguards. Bagwell and Staiger (1990. 2002) suggest that safeguard measures may be understood as a device for reducing the pressure on nations to cheat on trade agreements, and thus can reduce the danger that the agreements may unravel. Sykes (1991) argues that the opportunity to cmploy safcguard measures cx post may facilitate more trade concessions $c x$ ante in an environment where negotiators face political uncertainty about the consequences of their trade concessions. And the experience of the GATT suggests that if safeguard measures become unavailable, nations may retum to arrangements such as voluntary export restraints that are even worse from the $\exp$ post standpoint because no standard restricts their use or limits their duration - the political pressures to protect troubled industries through trade policy will remain regardless of the state of the law, as will their potential to cause mischief.

It is thus plausible that safeguard measures have a constructive role to play in the trading system. If they are to play any role at all going forward, however, the law must evolve in a way that makes clear to WTO mombers what circumstances are appropriate for safeguards. and how to go about demonstrating the existence of those circumstances. For the reasons given ahove, the trenty text is wocfully deficient in this regard, and the decisions of the Appellate Body have only compounded the problem.

Onc way or another. what is need is a fresh start. We can imagine it coming in two ways. First, the Appellate Body might change course dranatically, and initiate a "common law" evolution toward coherent standards for the use of safeguards, much as U.S. courts have done in fleshing out the vague and imprecise standards of the U.S. 
antitrust laws. To do so, however, the Appellate Body would have to abandon its insistence on grounding every principle in treaty text, in favor of ascertaining the "object and purpose" of the Safeguards Agreement from other sources, perhaps even by some direct appeal to economic theory. Such a process would represent a major departure from the Appellate Body's usual approach to cases, however, and many might question the legitimacy of such a departure. Alternatively, the WTO membership might siniply renegotiate the Agreenent on Safeguards, with an cye toward resolving the fundamental issues that we have identified (and no doubt some that we have not). At this writing, neither possibility appears terribly likely in the foreseeable future.

Whatever the near term likelihood of legal reform, the economic literature docs offer sone ideas on possible directions for change. A number of economic scholars advocate an interpretation of tbe legal prerequisites for safeguards that melds easily with basic price theory, an appronch that actually surfaced briefly in the reasoning of a few ITC Commissioners. ${ }^{78}$ Grossman (1986), Kelly (1988), and Irwin (2003) would divide the potential causes of injury into three groups: forces that cause shifts in the domestic supply schedule: forces that cause shifts in the domestic demand schedule: and forces that cause shifts in the import supply schedule. Any harm to the domestic industry that can be attributed to shifts in the import supply curve will be deemed to result from "increased imports;" any harm attributable to rising domestic costs that shift the domestic supply schedule will be deemed to result from causes other than increased imports. Likewise, harm due to shifts in domestic demand will be attributed to causes other than imports, unless the shif in demand is due to a price reduction on imperfectly substitutable imports. This approach also has the great virtue of economic coherence, shifting the inquiry to ask whether changing conditions of import supply, rather than increased quantities of inports, are causally responsible for injury. It does not, however, address the problem of what

${ }^{78}$ See U.S. International Trade Comniission, Wood Shakes and Shingles, Inv. No. TA201-56, Pub. No. 1826 (1986)(views of Commissioners Liebeler and Brunsdale). 
counts as an "unforeseen development," or whether such a requirement is desirable and appropriate. And we do not pretend that it would always be casy to implement as a practical matter. The data requirements for confident estimation of the pertinent supply and demand relationships may often be lacking. and the lask of identifying and specifying those relationships can be controversial.

Critics may also argue that the import supply approach is not the only coherent way to implement a safeguards system. and may preclude safeguard measures in cases where W7O members might agree they ought to be permissible. 'The old GATT' Hatter's Fur case noted above is instructive in this regard. The U.S. position in that case was that a decline in domestic demand for the types of hats produced by domestic firms was the "unforeseen development" that resulted in an import surge and that justified safeguards acticn. The working party appeared to accept this theory, at least in principle, while quibbling as to whether the facts supported it.

Sykes (2003) suggests a slightly different set of principles. Noting that the original structure of Article XIX was aimed at protecting against the "unforescen" consequences of trade concessions that might produce import surges, he suggests that safeguards may be appropriate when unanticipated shocks lead exporters to enjoy unanticipated prosperity while import-competing firms simultanenusly suffer severe and unexpected declines. Such an approach could permit a safeguard measure on the facts of the Hatter's Fur case. lor example. This approach too leaves many detuils to be worked out, most especially the issue of how to determine whether shocks are unanticipaled, and is no more than an initial step toward articulating the role of safeguards in the system.

Our goal here is not to opine definitively on the proper logic of safeguards. That task, of course, is a matter for the WTO membership. We simply suggest that cconomically-oriented scholars may offer some useful ideas for the reform of safeguards law, and that they can at least help to suggest what sort of framework will stand the test of logical coherence. Curremt WTO jurisprudence flunks that test mistrably, and without 
reform will continue to present insuperable obstacles to the use of safeguard measures. We are unsure about the systemic consequences of this state of affairs, but are by no means confident that the consequences are benign. 


\section{REFERENCES}

Bagwell. Kyle and Robert W' Staiger (1990). "A Theory of Managed Trade," American Economic Review' 80: 779-795.

Bagwell . Kyle and Robert W'. Staiger (2002). The Economics of the World Trading System (Cambridge MA: The MIT Press).

Grossinan. Gene M. (1986). "Imports as a Cause of Injury: The Case ol the U.S. Steel Industry," Joumal of International Ecunumics 20: 201-222.

Grossman, Gene M. and Petros C. Mavroidis (2004), "United States - Delinitive Safeguard Measures on Imports of Circular Welded Carbon Quality Line Pipe from Korea," in H. Horn \& P. C. Mavroidis eds.. The WTO Case law' of 2002, American Law Institute Reporters Serics (Cambridge UK: Cambridge University Press, forthcoming).

Hom. Henrik and Petros C. Mavroidis (2003). "United States - Safeguard Measures on Imports of Fresh, Chilled or Frozen Launb Meat from New Yealand and Australia: What Should be Required of a Safeguard Investigation?", in H. Horn \& P.C. Mavroidis eds.. The WTO Case Law of 2001. American Law Institute Reporters Series (Cambridge UK: Cumbridge University Press).

Kelly, Kenneth (1988). "The Analysis of Causality in Excape Clause Cases," Journal of Industrial Economics 37: 187-207.

Invin, Douglas (2003). "Causing Problems? The WTO Review of Cuusation and Injury Attribution in U.S. Section 201 Cases," World Trade Review" 2: 297-325.

McGovern, Edmond (1986). Intemational Trade Regulation. $2^{\text {md }}$ edition (London: Gobefield).

Pauwelyn, Joost (2004). "The Puzzle of WTO Saleguards and Regional Trade Agreements," Journal of International Ecomomic Law 7: 109-42.

Sykes, Alan O. (1991). "Protectionisn as a "Safeguard": A Positive Analysis of the GATT 'Escape Clause' with Nomative Speculations," University' of Chicago Law Review 58: 255-305.

Sykes, Alun O. (2003). "The Safeguards Mess: A Critique of Appellate Body Jurisprudence," World Trade Review" 2: 261-95.

Sykes. Alan O. (2004), "The Persistent P'uzeles of Safeguards: Lessons from the Steel Dispute," Journal of International Economic Law 7: 523-64. 
HeinOnline -- THE WTO CASE LAW OF 2003274 March 30, 2005 